Research Paper

\title{
Phase I and II Study of Gemcitabine and Vinorelbine in Heavily Pretreated Patients with Metastatic Breast Cancer and Review of the Literature
}

\author{
Pamela Abdayem¹, Marwan Ghosn², Vicente Valero33, Ronald Walters³, Banu Arun³, James L. Murray33, \\ Richard Theriault ${ }^{3}$, Debbie Frye ${ }^{3}$, and Nuhad K. Ibrahim ${ }^{3}$ \\ 1. Faculty of Medicine, Saint-Joseph University, Beirut, Lebanon. \\ 2. Professor, Chairman of the department of Hematology and Medical Oncology at Saint-Joseph University Faculty of Medicine, Beirut, \\ Lebanon. \\ 3. Department of Breast Medical Oncology, The University of Texas MD Anderson Cancer Center, TX, USA.
}

$\triangle$ Corresponding author: Nuhad K. Ibrahim, MD, FACP. Department of breast Medical Oncology, Unit 1354, The University of Texas MD Anderson cancer center, 1515 Holcombe Blvd. Houston, TX 77030. Phone: 713-792-2817; Fax: 713-794-4385; Email: nibrahim@mdanderson.org.

( ) Ivyspring International Publisher. This is an open-access article distributed under the terms of the Creative Commons License (http://creativecommons.org/ licenses/by-nc-nd/3.0/). Reproduction is permitted for personal, noncommercial use, provided that the article is in whole, unmodified, and properly cited.

Received: 2013.12.06; Accepted: 2014.02.01; Published: 2014.03.29

\begin{abstract}
Background: Many phase II trials investigated the combination of Gemcitabine (G) and Vinorelbine $(V)$ in the treatment of metastatic breast cancer (MBC) with variable outcomes. This study was conducted to explore whether this combination was effective and tolerable in MBC patients who were heavily pretreated with anthracyclines and taxanes. Methods: A phase I study was conducted first to establish the maximum tolerated dose (MTD) of the $G$ and $V$ combination in MBC patients. Then, a phase II study evaluated the response rates, the median time to progression (TTP), the overall survival (OS) as well as the toxicities resulting from this combination at the MTD. Results: Nine patients were enrolled in the phase I study. The MTD was identified as $700 \mathrm{mg} / \mathrm{m}^{2}$ of $\mathrm{G}$ on days $I$ and 8 in combination with $I 5 \mathrm{mg} / \mathrm{m}^{2}$ of $V$ on days 2 and 9 , every $2 I$ days. Twenty-one of 25 patients involved in the phase II study were evaluable for response. No complete or partial responses were achieved; 6 patients (24.0\%) had stable disease and $15(60.0 \%)$ progressed. The median TTP was 2 months and the median OS 10 months. Grade 3/4 Neutropenia was the major hematologic toxicity, occurring in $52 \%$ of the cycles. The most common non-hematologic grade $3 / 4$ toxicities were fatigue (18\%), myalgias (17\%) and arthralgias (13\%). Conclusion: In heavily pretreated patients with $M B C$, the combination of $G$ and $V$ at the doses stated above was ineffective as it did not induce partial or complete responses. Other chemotherapy agents or combinations should be evaluated in future studies.
\end{abstract}

Key words: Metastatic breast cancer, Gemcitabine, Vinorelbine, anthracycline, taxane.

\section{Introduction}

Anthracyclines and taxanes are the two most commonly used cytotoxic chemotherapy agents in the neoadjuvant and adjuvant treatment of breast cancer $[1,2]$. However, recurrent tumors may have relative resistance to both classes of agents. Therefore, there is an increasing need for anthracycline- or taxane-free regimens to treat recurrent breast cancer after neoadjuvant and adjuvant chemotherapy.

Gemcitabine (2', 2'-difluorodeoxycytidine) is a pyrimidine analog that is phosphorylated intracellularly to produce derivatives that inhibit DNA synthesis [3]. Many phase II studies have evaluated its use as 
a single agent in the treatment of metastatic breast cancer (MBC), with overall response rates of $14 \%$ to $37 \%$ as first-line therapy and approximately $12 \%$ to $30 \%$ as second-line therapy after prior taxanes or anthracyclines [4]. The main side effects of the drug are granulocytopenia, thrombocytopenia, and abnormal liver function tests. However, gemcitabine is most effective when administered with a taxane (docetaxel or paclitaxel) in the first- or second-line setting [5]. Favorable responses and manageable toxicity profiles have also been reported when it is used in combination with other chemotherapeutic agents, such as anthracyclines and platinum compounds [6-10].

Vinorelbine is a semi-synthetic vinca alkaloid that induces cytotoxicity by inhibiting microtubule assembly at the G2-M phase. Most studies of vinorelbine as monotherapy, with or without granulocyte colony-stimulating factor, showed a mean overall response rate of $25 \%$ [11, 12]. Vinorelbine in combination with taxanes, anthracyclines, or platinum agents has shown efficacy in phase II and III trials in patients with anthracycline- or taxane-resistant recurrent breast cancer and MBC [13-21].

Gemcitabine and vinorelbine have different mechanisms of anti-tumor activity, good therapeutic indices, and no overlapping toxicities, except for neutropenia. In addition, both drugs appear to be non-cross-resistant with anthracyclines and taxanes. Such characteristics make the combination of gemcitabine and vinorelbine a promising treatment for $\mathrm{MBC}$, especially in patients with previous exposure to taxanes or anthracyclines.

Multiple studies have been conducted in the past decade to evaluate the efficacy and tolerability of gemcitabine and vinorelbine in the treatment of advanced breast cancer or MBC. Response rates varied between studies and few of them included heavily pretreated patients. Here, we report the results of a phase I and II study of gemcitabine and vinorelbine in patients with $\mathrm{MBC}$ pretreated with anthracyclines and taxanes. The objectives of this study were to determine these drugs' maximum tolerated dose (MTD) and qualitative and quantitative toxicities, the toxicities' reversibility, and patients' response rate, time to progression (TTP), and survival duration.

\section{Patients and Methods}

\section{Patient selection}

All patients had histologically confirmed MBC and had been treated with two or more chemotherapy regimens in the metastatic setting. Consecutive eligible patients were recruited and treated at MD Anderson Cancer Center on an Investigational Review Board approved Phase I-II trial. Phase I patients were accrued between December 23, 1999 and December 1, 2000; phase II patients were accrued between December 29, 2000 and August 8, 2003. Pertinent information were retrieved from the electronic research data base that accessed and reviewed for the purpose of this report. Patients may have undergone hormonal therapy at any time. They were required to be $\geq 18$ years, have a life expectancy of $\geq 12$ weeks, have a Zubrod performance status of $\leq 2$, and have adequate bone marrow, liver, and kidney function, defined as follows: absolute neutrophil count (ANC) $\geq$ $1,500 / \mathrm{mcL}$, platelet count $\geq 100,000 / \mathrm{mcL}$, total bilirubin level within the upper limits of the normal range, aspartate aminotransferase and alanine aminotransferase levels of $\leq$ four times the upper limit of the normal range, and serum creatinine level of $\leq 2.5$ $\mathrm{mg} / \mathrm{dl}$. Patients were eligible if they had stable $\leq$ grade 1 peripheral neuropathy and if it had been $\geq 3$ weeks since radiation therapy or chemotherapy. All women of childbearing potential who did not use adequate contraception measures were excluded from the study, as were those with intercurrent medical conditions that were not well controlled by medication, concurrent active infections, neurotoxicity of $\geq$ grade 2, metastatic central nervous system disease diagnosed within the previous 6 months, or a history of another invasive malignancy. In addition, for the phase I study, patients were required to have measurable or evaluable disease by physical examination or radiological evaluation. MD Anderson institutional review board approval and patient informed consent were obtained in all cases.

\section{Treatment plan}

\section{Phase I study design}

Treatment was administered on an outpatient basis. Patients were treated with a starting dose of 700 $\mathrm{mg} / \mathrm{m}^{2}$ of gemcitabine by infusion, at a rate of $10 \mathrm{mg} /$ minute, on days 1 and 8 . The starting dose of vinorelbine infusion, given on days 2 and 9, was $20 \mathrm{mg} / \mathrm{m}^{2}$ over 10 minutes. The cycle duration was 21 days. Dose levels are listed in Table 1, and dose modifications were adjusted by roughly $20 \%$ increments.

If no patients developed grade 3 or 4 non-hematologic toxicity or dose-limiting granulocytopenia or thrombocytopenia at any dose level, three patients would be treated at the next dose level. If one of three patients developed a grade 3 or 4 toxicity, or dose-limiting granulocytopenia or thrombocytopenia, three patients would be entered at the same dose level. If only two of six patients experienced a dose-limiting toxicity (DLT), three more patients would be added at the lower level. If two of three patients developed a DLT, the next patient 
would be treated at a lower level. The MTD was one dose level below the dose at which three of six patients developed a grade 3 or 4 toxicity or dose-limiting granulocytopenia or thrombocytopenia. DLTs were febrile neutropenia (temperature $>38.1^{\circ} \mathrm{C}$ and ANC $<500 / \mathrm{mcL}$ ), neutrophil count $\leq 1,000 / \mathrm{mcL}$ by day 29 , and a platelet count $<20,000 / \mathrm{mcL}$ or one resulting in bleeding.

Table I. Dose levels of gemcitabine and vinorelbine

\begin{tabular}{|c|c|c|}
\hline Dose level & $\begin{array}{l}\text { Gemcitabine (days } 1 \\
\text { and } 8)\left(\mathrm{mg} / \mathrm{m}^{2}\right)\end{array}$ & $\begin{array}{l}\text { Vinorelbine (days } 2 \text { and } \\
\text { 9) }\left(\mathrm{mg} / \mathrm{m}^{2}\right)\end{array}$ \\
\hline-3 & 500 & 15 \\
\hline-2 & 600 & 15 \\
\hline-1 & 700 & 15 \\
\hline 0 & 700 & 20 \\
\hline 1 & 850 & 20 \\
\hline 2 & 1000 & 20 \\
\hline 3 & 1000 & 25 \\
\hline 4 & 1200 & 25 \\
\hline 5 & 1200 & 30 \\
\hline 6 & 1400 & 30 \\
\hline 7 & 1400 & 37 \\
\hline
\end{tabular}

\section{Phase II study design}

After the MTD had been determined, patients were treated at that dose level in the phase II study. All patients who underwent a minimum of two cycles of treatment were considered evaluable for response; however, if disease progressed rapidly, treatment was discontinued after one cycle and the condition was counted as progressive disease. TTP was defined as the period of time, on study, from the first day of treatment to when progressive disease was clearly documented. Survival duration was defined as the period of time from the first day of drug treatment to the date of death of the patient. All patients enrolled in the study were also evaluated for toxicity.

\section{Patient evaluation}

The pretreatment evaluation included a complete medical history and physical examination, with a performance status assessment. Hematological and full chemical work-ups were obtained, in addition to testing for tumor markers CA 27.29 and CEA. Imaging studies included chest $\mathrm{x}$-ray, computed tomography, abdominal sonography, bone scan, plain films of areas of suspicious increased activity, and magnetic resonance imaging. The on-study evaluation included a complete physical examination during the week preceding therapy and every 3 weeks thereafter; a hematological survey on days $8,12,15$, and 21 during the first two cycles and weekly for subsequent treatments; a chemistry profile, repeated every 6 weeks (SGPT, LDH, alkaline phosphatase, total bilirubin,
BUN, creatinine, glucose, and calcium), and tumor markers CA 27.29 or CEA (every 6 weeks if initially elevated and every 12 weeks if not). All cancer-related symptoms and drug-associated adverse experiences were recorded every 3 weeks, per NCI Common Toxicity Criteria guidelines. Tumor measurements were obtained through physical examination or chest radiography every 6 weeks and through sonography, CT, MRI, bone scan, or bone radiography every 8 weeks when indicated. Patients were allowed to remain in the study in the absence of progressive disease or unacceptable toxicities, which were defined as unpredictable, irreversible, or grade 4 non-hematologic toxicities.

\section{Results}

\section{Patient characteristics}

Overall, 34 anthracycline- and taxane-pretreated MBC patients were enrolled in the study. As neoadjuvant or adjuvant, 8 patients had anthracycline and taxane; 10 patients had anthracycline with/out cyclophosphamide, methotrexate and flourauracil (CMF) and 4 patients had CMF only; 8 patients presented with no adjuvant or neoadjuvant chemotherapy. All patients were vinorelbine, gemcitabine or platinum compounds naïve. One patient received capecitabine in the adjuvant setting and 28 patients received it in the metastatic setting. Only 5 patients received trastuzumab: one in the adjuvant setting and 4 in the metastatic setting.

The phase I study involved nine patients, and phase II included 25. Patients' characteristics are shown in Table 2. All patients were women; most were white $(74 \%)$, with a median age of 52 years and a performance status of $1(62 \%)$. Fourteen patients (41\%) had positive estrogen receptor status, and most $(79 \%)$ had visceral disease. All patients had undergone chemotherapy with a median of three different regimens prior to enrollment; 21 (62\%) had undergone chemotherapy in both the adjuvant and metastatic settings. Twenty-four (71\%) patients had undergone radiation therapy as well, and $15(44 \%)$ had undergone hormonal therapy.

\section{Phase I study}

\section{Dose escalation and DLT}

Nine patients (three entered at level 0 and six at level -1) received a total of 54 cycles, with interpatient dose adjustment based on toxicities (Table 3). Six cycles were administered at dose level 0 , with a median ANC nadir of $850 / \mathrm{mcL}$ and a median platelet count nadir of $106,000 / \mathrm{mcL} ; 28$ at dose level -1 , with a median ANC nadir of $900 / \mathrm{mcL}$ and a median platelet count nadir of $92,000 / \mathrm{mcL} ; 18$ at dose level -2 , with a 
median ANC nadir of $1,240 / \mathrm{mcL}$ and a median platelet count nadir of $131,000 / \mathrm{mcL}$; and two at dose level -3, with a median ANC nadir of $1,110 / \mathrm{mcL}$ and a median platelet count nadir of $112,000 / \mathrm{mcL}$. In conclusion, $700 \mathrm{mg} / \mathrm{m}^{2}$ of gemcitabine on days 1 and 8 , in combination with $15 \mathrm{mg} / \mathrm{m}^{2}$ of vinorelbine on days 2 and 9 , given in a cycle of 21 days, was considered a safe dose level for most patients.

Table 2. Patient characteristics. All patients were female, and all underwent both taxane and anthracycline therapy.

\begin{tabular}{|c|c|c|c|}
\hline Patient characteristic & Phase I & Phase II & Total \\
\hline Number of patients & 9 & 25 & 34 \\
\hline Median age, years (range) & $50(31-69)$ & $52(38-70)$ & $52(31-70)$ \\
\hline \multicolumn{4}{|l|}{ Ethnic group, n (\%) } \\
\hline Black & $0(0)$ & $4(16)$ & $4(12)$ \\
\hline Hispanic & $1(11)$ & $4(16)$ & $5(15)$ \\
\hline Non-Hispanic white & $8(89)$ & $17(68)$ & $25(74)$ \\
\hline \multicolumn{4}{|c|}{ ECOG performance status, $\mathrm{n}(\%)$} \\
\hline 0 & $3(33)$ & $7(28)$ & $10(29)$ \\
\hline 1 & $4(44)$ & $17(68)$ & $21(62)$ \\
\hline 2 & $2(22)$ & $1(4)$ & $3(9)$ \\
\hline \multicolumn{4}{|c|}{ Estrogen receptor status, $\mathrm{n}(\%)$} \\
\hline Positive & $6(67)$ & $8(32)$ & $14(41)$ \\
\hline Negative & $3(33)$ & $17(68)$ & $20(59)$ \\
\hline \multicolumn{4}{|c|}{ Prior hormonal therapy, n (\%) } \\
\hline Yes & $6(67)$ & $9(36)$ & $15(44)$ \\
\hline No & $3(33)$ & $16(64)$ & $19(56)$ \\
\hline \multicolumn{4}{|l|}{ Prior radiation therapy, $\mathrm{n}(\%)$} \\
\hline Adjuvant & $4(44)$ & $10(40)$ & $14(41)$ \\
\hline Metastatic & $2(22)$ & $4(16)$ & $6(18)$ \\
\hline Adjuvant and metastatic & $0(0)$ & $4(160)$ & $4(12)$ \\
\hline None & $3(33)$ & $7(28)$ & $10(29)$ \\
\hline \multicolumn{4}{|c|}{$\begin{array}{l}\text { Number of prior chemotherapy } \\
\text { regimens, } \mathrm{n}(\%)\end{array}$} \\
\hline 2 & $2(22)$ & $2(8)$ & $4(12)$ \\
\hline 3 & $3(33)$ & $16(64)$ & $19(56)$ \\
\hline 4 & $3(33)$ & $5(20)$ & $8(24)$ \\
\hline 5 or 6 & $1(11)$ & $2(8)$ & $3(9)$ \\
\hline \multicolumn{4}{|c|}{$\begin{array}{l}\text { Prior chemotherapy setting, } n \\
(\%)\end{array}$} \\
\hline Adjuvant & $0(0)$ & $1(4)$ & $1(3)$ \\
\hline Metastatic & $5(56)$ & $7(28)$ & $12(35)$ \\
\hline Adjuvant and metastatic & $4(44)$ & $17(68)$ & $21(62)$ \\
\hline \multicolumn{4}{|c|}{ Number of disease sites, $\mathrm{n}(\%)$} \\
\hline 1 & $2(22)$ & $5(20)$ & $7(21)$ \\
\hline 2 & $3(33)$ & $9(36)$ & $12(35)$ \\
\hline 3 & $0(0)$ & $2(8)$ & $2(6)$ \\
\hline 4 & $2(22)$ & $6(24)$ & $8(24)$ \\
\hline 5 or 6 & $2(22)$ & $3(12)$ & $5(15)$ \\
\hline \multicolumn{4}{|c|}{ Dominant site of disease, $\mathrm{n}(\%)$} \\
\hline Soft tissue & $0(0)$ & $4(16)$ & $4(12)$ \\
\hline Bone & $1(11)$ & $2(8)$ & $3(9)$ \\
\hline Visceral & $8(89)$ & $19(76)$ & $27(79)$ \\
\hline
\end{tabular}

Table 3. Number of cycles and hematologic nadirs, according to gemcitabine and vinorelbine dose levels, in phase I. Abbreviations: G, gemcitabine; V, vinorelbine; AGC, absolute granulocyte count.

\begin{tabular}{llll}
\hline $\begin{array}{l}\text { Dose level } \\
\left(\mathrm{mg} / \mathrm{m}^{2}\right)\end{array}$ & $\begin{array}{l}\text { Number of } \\
\text { cycles }\end{array}$ & $\begin{array}{l}\text { AGC nadir (range) } \\
(1,000 \mathrm{u} / \mathrm{mcL})\end{array}$ & $\begin{array}{l}\text { Platelets nadir } \\
(\text { range })(1,000 \\
\mathrm{u} / \mathrm{mcL})\end{array}$ \\
\hline All cycles & 54 & $1.01(0.01-3.06)$ & $102(33-358)$ \\
$0: \mathrm{G}=700, \mathrm{~V}=20$ & 6 & $0.85(0.04-1.10)$ & $106(55-358)$ \\
$-1: \mathrm{G}=700, \mathrm{~V}=15$ & 28 & $0.90(0.01-2.32)$ & $92(43-278)$ \\
$-2: \mathrm{G}=600, \mathrm{~V}=15$ & 18 & $1.24(0.08-3.06)$ & $131(33-302)$ \\
$-3: \mathrm{G}=500, \mathrm{~V}=15$ & 2 & $1.11(1.01-1.20)$ & $112(84-139)$ \\
\hline
\end{tabular}

Table 4. Incidence of $\mathrm{NCl}$ Common Toxicity Criteria grades 2, 3, and 4 adverse effects in phase I study (per cycle)

\begin{tabular}{lllll}
\hline Toxicity (n=54) & \multicolumn{3}{l}{ Grade, $\mathrm{n}(\%)$} \\
\cline { 2 - 4 } & 2 & 3 & 4 & Total \\
\hline Non-hematologic & & & & \\
Abdominal pain & $2(4)$ & $0(0)$ & $0(0)$ & $2(4)$ \\
Alopecia & $35(65)$ & $\mathrm{NA}$ & $\mathrm{NA}$ & $35(65)$ \\
Arthralgias & $0(0)$ & $0(0)$ & $0(0)$ & $0(0)$ \\
Constipation & $7(13)$ & $2(4)$ & $0(0)$ & $9(17)$ \\
Diarrhea & $4(7)$ & $0(0)$ & $0(0)$ & $4(7)$ \\
Fatigue & $19(35)$ & $8(15)$ & $0(0)$ & $27(50)$ \\
Headache & $5(9)$ & $0(0)$ & $0(0)$ & $5(9)$ \\
Mucositis & $6(11)$ & $0(0)$ & $0(0)$ & $6(11)$ \\
Myalgias & $20(37)$ & $7(13)$ & $0(0)$ & $27(50)$ \\
Nausea & $11(20)$ & $2(4)$ & $0(0)$ & $13(24)$ \\
Neutropenic fever & $0(0)$ & $1(2)$ & $0(0)$ & $1(2)$ \\
Neutropenic infection & $0(0)$ & $0(0)$ & $0(0)$ & $0(0)$ \\
Non-neutropenic fever & $5(9)$ & $0(0)$ & $0(0)$ & $5(9)$ \\
Non-neutropenic infec- & $0(0)$ & $2(4)$ & $0(0)$ & $2(4)$ \\
tion & & & & \\
Paresthesias & $10(19)$ & $0(0)$ & $0(0)$ & $10(19)$ \\
Rash/pruritus & $2(4)$ & $0(0)$ & $0(0)$ & $2(4)$ \\
Vomiting & $5(9)$ & $0(0)$ & $0(0)$ & $5(9)$ \\
Hematologic & & & & \\
Neutropenia & $16(30)$ & $14(26)$ & $12(22)$ & $42(78)$ \\
Thrombocytopenia & $11(20)$ & $2(4)$ & $0(0)$ & $13(24)$ \\
Anemia & $8(15)$ & $2(4)$ & $1(2)$ & $11(20)$ \\
\hline
\end{tabular}

\section{Toxicity}

Overall, the chemotherapy regimen was well tolerated (Table 4). All administered cycles were evaluable for hematologic and non-hematologic toxicities. The most common grade 2 non-hematologic toxicities were alopecia (65\% of courses), myalgias $(37 \%)$, and fatigue $(35 \%)$. Grade 3 fatigue and myalgias were reported in $15 \%$ and $13 \%$ of cycles, respectively. No grade 4 non-hematologic toxicities were observed. Grade 2 neutropenia, thrombocytopenia, and anemia were present in $30 \%, 20 \%$, and $15 \%$ of cycles, respectively. Grade 3 neutropenia, thrombocytopenia, and anemia were present in $26 \%, 4 \%$, and $4 \%$. Grade 4 neutropenia and anemia occurred in $22 \%$ and $2 \%$, respectively; no grade 4 thrombocytopenia was reported. 
The MTD was identified as $700 \mathrm{mg} / \mathrm{m}^{2}$ of gemcitabine on days 1 and 8 and $15 \mathrm{mg} / \mathrm{m}^{2}$ of vinorelbine on days 2 and 9.

\section{Phase II study}

\section{Response evaluation}

One patient in the phase I study had non-evaluable disease at baseline and was not evaluable for response. No responses were observed among the eight evaluable patients. The median TTP was 5 months (range, 1-12 months), and the median overall survival duration was 12 months (range, 2-46 months). Among the 25 patients treated in phase II, 21 were evaluable for response. The others developed central nervous system disease at the beginning of cycle 1 (one patient) or an intractable headache (one patient), were transferred to private oncologist care per patient request (one patient), or died of an unclear cause (one patient). With a median number of two cycles per patient, no complete or partial remissions were experienced (Table 5); only six patients $(24 \%)$ had stable disease, and $15(60 \%)$ experienced progression during therapy. The median TTP was 2 months (range, 1-6 months) and the median overall survival duration was 10 months (range, 1-36 months).

Overall, of the 34 patients who entered the study (phases I and II), 29 were evaluable for response. With a median number of 2.5 cycles per patient, no complete or partial remissions were achieved. Thirteen patients (38\%) had stable disease, whereas $16(47 \%)$ experienced progression. The median TTP was 2 months (range, 1-12 months), and the median overall survival duration was 11 months (range, 1-46 months).

Table 5. Response rates, TTP, and overall survival in phase I and II studies

\begin{tabular}{|c|c|c|c|}
\hline Study Clinical Outcomes & Phase I & Phase II & Total \\
\hline Number of patients & 9 & 25 & 34 \\
\hline Median number of cycles (range) & $4(2-14)$ & $2(1-12)$ & $2.5(1-14)$ \\
\hline \multicolumn{4}{|l|}{ Tumor response, n (\%) } \\
\hline Complete & $0(0.0)$ & $0(0.0)$ & $0(0.0)$ \\
\hline Partial & $0(0.0)$ & $0(0.0)$ & $0(0.0)$ \\
\hline Stable disease & $7(77.8)$ & $6(24.0)$ & $13(38.2)$ \\
\hline Progressive disease & 1 (11.1) & $15(60.0)$ & $16(47.1)$ \\
\hline Non-evaluable & $1(11.1)$ & $4(16.0)$ & $5(14.7)$ \\
\hline Median TTP (months) & 5 & 2 & 2 \\
\hline TTP range (months) & $1-12$ & $1-6$ & $1-12$ \\
\hline $\begin{array}{l}\text { Median overall survival duration } \\
\text { (months) }\end{array}$ & 12 & 10 & 11 \\
\hline OS duration range (months) & $2-46$ & $1-36$ & $1-46$ \\
\hline
\end{tabular}

\section{Toxicity}

In the phase II study, 71 of the 76 administered cycles were evaluable for hematologic toxicity, with a median ANC nadir of $970 / \mathrm{mcL}$ and a median platelet count nadir of $136,000 / \mathrm{mcL}$ (Table 6). Sixty courses were given at dose level -1 , with a median ANC nadir of $1,010 / \mathrm{mcL}$ and a platelet count nadir of $140,000 / \mathrm{mcL}$. Dose reduction was necessary in six patients who underwent 10 courses at dose level -2, with a median ANC nadir of $860 / \mathrm{mcL}$ and a median platelet count nadir of $70,000 / \mathrm{mcL}$; another patient underwent one course at dose level -3 , with a median ANC nadir of $610 / \mathrm{mcL}$ and a median platelet count nadir of 163,000/mcL. Grade 2 neutropenia, thrombocytopenia, and anemia were present in $20 \%, 13 \%$, and $41 \%$ of cycles, respectively. Grade 3 neutropenia, thrombocytopenia, and anemia were present in $38 \%$, $1 \%$, and $1 \%$. Grade 4 neutropenia occurred in $14 \%$ of the cycles, whereas no grade 4 thrombocytopenia or anemia were reported (Table 7).

Table 6. Phase II number of cycles and hematologic nadirs according to gemcitabine and vinorelbine dose levels

\begin{tabular}{llll}
\hline $\begin{array}{l}\text { Dose level } \\
\left(\mathrm{mg} / \mathrm{m}^{2}\right)\end{array}$ & $\begin{array}{l}\text { Number } \\
\text { of cycles }\end{array}$ & $\begin{array}{l}\text { AGC nadir (range) } \\
(1,000 \mathrm{u} / \mathrm{mcL})\end{array}$ & $\begin{array}{l}\text { Platelets nadir } \\
\text { (range) }(1,000 \\
\mathrm{u} / \mathrm{mcL})\end{array}$ \\
\hline All cycles & 71 & $0.97(0.08-6.46)$ & $136(41-437)$ \\
$-1: \mathrm{G}=700, \mathrm{~V}=15$ & 60 & $1.01(0.08-6.46)$ & $140(60-375)$ \\
$-2: \mathrm{G}=600, \mathrm{~V}=15$ & 10 & $0.86(0.21-4.21)$ & $70(41-437)$ \\
$-3: \mathrm{G}=500, \mathrm{~V}=15$ & 1 & $0.61(0.61-0.61)$ & $163(163-163)$ \\
\hline
\end{tabular}

Table 7. Incidence of $\mathrm{NCl}$ Common Toxicity Criteria grade 2, 3, and 4 adverse effects in phase II study (per cycle)

\begin{tabular}{lllll}
\hline Toxicity & \multicolumn{4}{c}{ Grade, $\mathrm{n}(\%)$} \\
\cline { 2 - 5 } Non-hematologic (n=76) & \multicolumn{4}{c}{3} \\
Abdominal pain & $1(1.3)$ & $1(1.3)$ & $0(0.0)$ & $2(2.6)$ \\
Alopecia & $26(34.2)$ & $\mathrm{NA}$ & $\mathrm{NA}$ & $26(34.2)$ \\
Arthralgias & $3(3.9)$ & $9(11.8)$ & $1(1.3)$ & $12(15.8)$ \\
Constipation & $9(11.8)$ & $1(1.3)$ & $0(0.0)$ & $10(13.2)$ \\
Diarrhea & $5(6.6)$ & $0(0.0)$ & $0(0.0)$ & $5(6.6)$ \\
Fatigue & $32(42.1)$ & $13(17.1)$ & $1(1.3)$ & $45(59.2)$ \\
Headache & $1(1.3)$ & $1(1.3)$ & $0(0.0)$ & $2(2.6)$ \\
Mucositis & $4(5.3)$ & $0(0.0)$ & $0(0.0)$ & $4(5.3)$ \\
Myalgias & $21(27.6)$ & $13(17.1)$ & $0(0.0)$ & $34(44.7)$ \\
Nausea & $20(26.3)$ & $2(2.6)$ & $0(0.0)$ & $22(28.9)$ \\
Neutropenic fever & $0(0.0)$ & $1(1.3)$ & $0(0.0)$ & $1(1.3)$ \\
Neutropenic infection & $0(0.0)$ & $1(1.3)$ & $0(0.0)$ & $1(1.3)$ \\
Non-neutropenic fever & $5(6.6)$ & $0(0.0)$ & $0(0.0)$ & $5(6.6)$ \\
Non-neutropenic infection & $1(1.3)$ & $1(1.3)$ & $0(0.0)$ & $2(2.6)$ \\
Paresthesias & $4(5.3)$ & $2(2.6)$ & $0(0.0)$ & $6(7.9)$ \\
Rash/pruritus & $4(5.3)$ & $1(1.3)$ & $0(0.0)$ & $5(6.6)$ \\
Vomiting & $6(7.9)$ & $4(5.3)$ & $0(0.0)$ & $10(13.2)$ \\
Hematologic (n=71) & & & & \\
Neutropenia & $14(19.7)$ & $27(38.0)$ & $10(14.1)$ & $51(71.8)$ \\
Thrombocytopenia & $9(12.7)$ & $1(1.4)$ & $0(0.0)$ & $10(14.1)$ \\
Anemia & $29(40.8)$ & $1(1.4)$ & $0(0.0)$ & $30(42.3)$ \\
\hline
\end{tabular}


The most common non-hematologic grade 2 toxicities (Table 7) were fatigue ( $42 \%$ of the cycles), alopecia (34\%), myalgias (28\%), nausea $(26 \%)$, and constipation (12\%). Grade 3 fatigue, myalgias, and arthralgias were reported in $17 \%, 17 \%$, and $12 \%$ of the cycles, respectively. Grade 4 fatigue and arthralgias each occurred in one cycle $(1 \%)$.

\section{Discussion}

Few chemotherapy agents or combinations have demonstrated significant activity in anthracycline- or taxane-pretreated MBC patients. Although the combination of gemcitabine and vinorelbine has not often been used in treatment, it may be an effective treatment because both agents have different mechanisms of action, with no overlapping toxicities (except for neutropenia) and only partial non-cross resistance with anthracyclines and taxanes.

Between 1999 and 2012, many phase II trials (Table 8) investigated the combination of gemcitabine and vinorelbine, at various dosages, in the treatment of MBC patients; the activity level was encouraging, and the toxicity profile was acceptable. In fact, response rates in phase II studies [22-39] ranged from $22.0 \%$ to $55.5 \%$, depending on patient characteristics, drug doses and schedules, and the type of previously administered chemotherapy. TTP ranged from 3.5 to 10.8 months, and the overall survival duration ranged from 9.2 to 20 months. Toxicity was generally moderate. The major hematologic adverse effects were grade 3 or 4 neutropenia, which occurred in up to $52.0 \%$ of patients, and thrombocytopenia, which occurred in up to $20.0 \%$. The most common grade 3 or 4 non-hematologic toxicities were nausea and vomiting ( $0.0 \%$ to $26.0 \%)$, constipation $(0.0 \%$ to $14.0 \%)$, liver toxicity $(0.0 \%$ to $10.0 \%)$, and fatigue $(0.0 \%$ to $13.3 \%)$.

As a "second-line" neoadjuvant treatment in locally advanced breast cancer with no early response to docetaxel, doxorubicin, and cyclophosphamide, the combination of gemcitabine and vinorelbine was found to be both efficacious and relatively safe in a prospective phase II study conducted by Halim et al in 2011. A clinical response was achieved in 35 cases $(50.0 \%)$, and a pathological response was reported in four cases $(5.7 \%)$. Breast-conserving surgery became possible in 31 cases $(44.0 \%)$. The most common grade 3 and 4 toxicities were neutropenia and thrombocytopenia in $25.7 \%$ and $22.8 \%$ of cases, respectively. Toxicities were reversible and did not cause death [40].

After establishing an MTD of the dose schedule investigated in phase I study $\left(700 \mathrm{mg} / \mathrm{m}^{2}\right.$ of gemcitabine by infusion on days 1 and 8 and $15 \mathrm{mg} / \mathrm{m}^{2}$ of vinorelbine by infusion on days 2 and 9, every 3 weeks), we treated 25 patients in phase II to deter- mine efficacy. Among the 21 patients evaluable for response, no complete or partial remissions were achieved. The median TTP was 2 months, and the median overall survival duration was 10 months.

These results are disappointing and are not consistent with those of any previous studies of the gemcitabine and vinorelbine combination. Three hypotheses may explain our results. First, the doses in this study were inferior to those in all but one other phase II study, in which, paradoxically, $350 \mathrm{mg} / \mathrm{m}^{2}$ of gemcitabine on days 1 and 8 and $25 \mathrm{mg} / \mathrm{m}^{2}$ of vinorelbine on days 1 and 8 every 3 weeks resulted in a response rate of $30.4 \%$, a TTP of 4.6 months, and an overall survival duration of 14.5 months [32].The starting doses of gemcitabine and vinorelbine that we used were based on the results of our phase I study, in which neutropenia was the major adverse effect (grade 3 or 4 neutropenia in $48 \%$ of cycles). Second, gemcitabine was administered on days 1 and 8 of the cycle and vinorelbine on days 2 and 9, whereas in most other studies, both drugs were given on days 1 and 8. Third, few previous studies included heavily pretreated MBC patients, whereas all patients in our study had undergone a median of three prior chemotherapy regimens: $97 \%$ underwent chemotherapy in the metastatic setting and $62 \%$ in the adjuvant and metastatic settings; all patients had received both anthracyclines and taxanes in the past. Consequently, our patients were more heavily pretreated than were those in most studies. Kim et al presented a similar patient profile and a response rate of $30 \%$; however, the TTP and overall survival duration were similar to our results of 3.9 and 10.8 months, respectively [37]. The difference in the response rate may result from the increased doses $\left(1000 \mathrm{vs} 700 \mathrm{mg} / \mathrm{m}^{2}\right.$ of gemcitabine and 25 vs $15 \mathrm{mg} / \mathrm{m}^{2}$ of vinorelbine) and the greater number of patients ( 57 vs 25 ) in Kim et al's study when compared with ours.

Grade 3 and 4 neutropenia was the major hematologic toxicity in our study, occurring in $52 \%$ of cycles and $56 \%$ of patients; this is similar to the findings of other studies, even though our doses were inferior to those of all but one other phase II study. The number of grade 3 or 4 thrombocytopenia cases, however, was minimal compared with that in other studies. As for non-hematologic adverse effects, more of our patients reported grade 3 or 4 fatigue $(18 \%$ of cycles), myalgias (17\%), and arthralgias $(13 \%)$, but fewer experienced grade 3 or 4 constipation (1\%), nausea $(3 \%)$, and vomiting (5\%).

The results of a few recently conducted studies are well-matched with ours. In 2007, in a phase III study, Martin et al found that anthracycline- and taxane-pretreated MBC patients treated with gemcitabine and vinorelbine had a longer progression-free 
survival than did those treated with vinorelbine alone; however, there was no difference in overall survival. They also experienced more hematologic toxicities [41]. In addition, in a 2011 randomized phase II trial comparing gemcitabine plus vinorelbine, gemcitabine plus cisplatin, and gemcitabine plus capecitabine in 141 patients with pretreated MBC, similar results were found regarding treatment efficacy (overall response rates, $39.0 \%, 47.7 \%$, and $34.7 \%$; median progression-free survival durations, 5.7, 6.9, and 8.3 months; and median overall survival duration, 17.5, 13.0, and 19.4 months, respectively) and toxicity (mainly grade 3 or 4 neutropenia, $16.7 \%, 4.4 \%$, and $0.0 \%$, respectively) [42]. Pallis et al performed a multicenter randomized phase III trial of vinorelbine and gemcitabine doublet versus capecitabine mono- therapy in 74 anthracycline- and taxane-pretreated women with MBC in 2011 and found that the combination was not superior in terms of progression-free survival(5.4 vs 5.2 months, respectively; $p=0.736$ ). Given the favorable toxicity and convenience of oral administration, single-agent capecitabine was recommended for compliant patients [43]. In another recent randomized phase II non-comparative study of pemetrexed-carboplatin and gemcitabine-vinorelbine for the treatment of anthracycline- and taxane-pretreated advanced breast cancer, patients experienced response rates of $26.6 \%$ and $29.5 \%$, respectively, and a median TTP of $5.1 \%$ and $5.6 \%$, respectively. According to the authors, both combinations, although well tolerated, showed moderate activity, as the predefined response rate was not reached [44].

Table 8. Results of phase II studies regarding the efficacy of the combination Gemcitabine and Vinorelbine in metastatic breast cancer patients between 1999 and 2012 .

\begin{tabular}{|c|c|c|c|c|c|c|c|}
\hline Study (year) & Schedule & Clinical Setting & $\begin{array}{l}\text { Number } \\
\text { of pa- } \\
\text { tients }\end{array}$ & $\begin{array}{l}\text { Response } \\
\text { rate }(\%)\end{array}$ & $\begin{array}{l}\text { Median } \\
\text { TTP/OS } \\
\text { (months) }\end{array}$ & $\begin{array}{l}\text { WHO Grade } 3 / 4 \\
\text { hematologic toxici- } \\
\text { ties per patient } \\
(\%)\end{array}$ & $\begin{array}{l}\text { WHO Grade } 3 / 4 \\
\text { Non-hematologic toxici- } \\
\text { ties per patient } \\
(\%)\end{array}$ \\
\hline $\begin{array}{l}\text { Haider et al[22] } \\
\text { (1999) }\end{array}$ & $\begin{array}{l}\mathrm{G}=1000 \mathrm{mg} / \mathrm{m} 2 \\
\text { Days } 1,15, \text { and } 21 \\
\mathrm{~V}=40 \mathrm{mg} / \mathrm{m} 2 \\
\text { Days } 1 \text { and } 21 \\
+ \\
\text { G-CSF } \\
\text { Every } 5 \text { weeks }\end{array}$ & $\begin{array}{l}\text { First line } \\
\text { Second line }\end{array}$ & $\begin{array}{l}45 \\
15\end{array}$ & $\begin{array}{l}55.5 \\
40\end{array}$ & $\begin{array}{l}9.5 />14 \\
7.0 / 12.2\end{array}$ & $\begin{array}{l}\mathrm{N}: 18 \\
\mathrm{~T}: 0 \\
\mathrm{~A}: 3\end{array}$ & $\begin{array}{l}\text { N/V: } 5 \\
\text { Constipation: } 3\end{array}$ \\
\hline $\begin{array}{l}\text { Valenza et al[23] } \\
(2000)\end{array}$ & $\begin{array}{l}\mathrm{G}=1000 \mathrm{mg} / \mathrm{m} 2 \\
\text { Days } 1,8, \text { and } 15 \\
\mathrm{~V}=30 \mathrm{mg} / \mathrm{m} 2 \\
\text { Days } 1 \text { and } 8 \\
\text { Every } 4 \text { weeks }\end{array}$ & $\begin{array}{l}\text { Pretreated with } \\
\text { Anthracyclines and } \\
\text { taxanes }\end{array}$ & 29 & 48 & $6.8 / 9.2$ & $\begin{array}{l}\mathrm{L}: 48 \\
\mathrm{~T}: 10\end{array}$ & None \\
\hline $\begin{array}{l}\text { Nicolaides et } \\
\text { al[24] } \\
(2000)\end{array}$ & $\begin{array}{l}\mathrm{G}=1000 \mathrm{mg} / \mathrm{m} 2 \\
\text { Days } 1 \mathrm{and} 8 \\
\mathrm{~V}=30 \mathrm{mg} / \mathrm{m} 2 \\
\text { Days } 1 \text { and } 8 \\
\text { Every } 3 \text { weeks }\end{array}$ & $\begin{array}{l}\text { Second-line treatment } \\
\text { after taxanes }\end{array}$ & 31 & 22 & $3.5 / 9.5$ & $\begin{array}{l}\mathrm{N}: 48 \\
\mathrm{~T}: 3\end{array}$ & $\begin{array}{l}\text { Rash: } 10 \\
\text { Neuropathy: } 3\end{array}$ \\
\hline $\begin{array}{l}\text { Mariani et al[25] } \\
(2001)\end{array}$ & $\begin{array}{l}\mathrm{G}=1200 \mathrm{mg} / \mathrm{m} 2 \\
\text { Days } 1 \text { and } 8 \\
\mathrm{~V}=30 \mathrm{mg} / \mathrm{m} 2 \\
\text { Days } 1 \text { and } 8 \\
\text { Every } 3 \text { weeks }\end{array}$ & $\begin{array}{l}\text { Pretreated except for } 1 \\
\text { patient } \\
\text { Phase I/II study }\end{array}$ & $\begin{array}{l}31 \\
\text { (phase II) }\end{array}$ & 22 & $\begin{array}{l}\text { ND/20 } \\
\text { (MDR: 12) }\end{array}$ & $\begin{array}{l}\text { N: } 48 \\
\text { T: } 6 \\
\text { A: } 6\end{array}$ & $\begin{array}{l}\text { N/V: } 3 \\
\text { Liver toxicity: } 10 \\
\text { Constipation: } 3\end{array}$ \\
\hline $\begin{array}{l}\text { Sanal et al[26] } \\
(2002)\end{array}$ & $\begin{array}{l}\mathrm{G}=1200 \mathrm{mg} / \mathrm{m} 2 \\
\text { Days } 1 \text { and } 8 \\
\mathrm{~V}=30 \mathrm{mg} / \mathrm{m} 2 \\
\text { Days } 1 \text { and } 8 \\
\text { Every } 3 \text { weeks }\end{array}$ & Pretreated & 32 & 44 & $5 / \mathrm{ND}$ & $\begin{array}{l}\mathrm{L}: 37.5 \\
\mathrm{~T}: 12.5\end{array}$ & $\begin{array}{l}\text { Phlebitis: } 15.6 \\
\text { Liver toxicity: } 3.1\end{array}$ \\
\hline $\begin{array}{l}\text { Stathopoulos } \\
\text { et al[27] } \\
(2002)\end{array}$ & $\begin{array}{l}\mathrm{G}=1000 \mathrm{mg} / \mathrm{m} 2 \\
\text { Day } 1 \\
\mathrm{~V}=25 \mathrm{mg} / \mathrm{m} 2 \\
\text { Day } 1 \\
\text { Every } 2 \text { weeks }\end{array}$ & $\begin{array}{l}\text { Pretreated with an- } \\
\text { thracyclines } \\
50 \% \text { also treated with } \\
\text { taxanes }\end{array}$ & 50 & 54 & $6 / 11.5$ & None & None \\
\hline $\begin{array}{l}\text { Donadio et } \\
\text { al[28] (2003) }\end{array}$ & $\begin{array}{l}\mathrm{G}=1000 \mathrm{mg} / \mathrm{m} 2 \\
\text { Days } 1 \text { and } 8 \\
\mathrm{~V}=25 \mathrm{mg} / \mathrm{m} 2 \\
\text { Days } 1 \text { and } 8 \\
\text { Every } 3 \text { weeks }\end{array}$ & $\begin{array}{l}\text { Pretreated with an- } \\
\text { thracyclines } \\
2^{\text {nd }} \text { or } 3^{\text {rd line }} \text { treatment }\end{array}$ & 51 & 33,3 & $10.8 / 17.8$ & $\mathrm{~N}: 11$ & N/V: 6 \\
\hline $\begin{array}{l}\text { Morabito et } \\
\text { al[29] (2003) }\end{array}$ & $\begin{array}{l}\mathrm{G}=800 \mathrm{mg} / \mathrm{m} 2 \\
\text { Days } 1 \text { and } 8 \\
\mathrm{~V}=25 \mathrm{mg} / \mathrm{m} 2 \\
\text { Days } 1 \text { and } 8 \\
\text { Every } 3 \text { weeks }\end{array}$ & $\begin{array}{l}\text { Phase I/II study } \\
\text { Pretreated with an- } \\
\text { thracyclines } \\
\text { With or without taxanes }\end{array}$ & $\begin{array}{l}50 \\
\text { (phase II) }\end{array}$ & 42 & $6 />18$ & $\begin{array}{l}\mathrm{N}: 34 \\
\mathrm{~A}: 8\end{array}$ & $\begin{array}{l}\text { Stomatitis: } 6 \\
\text { Liver toxicity: } 2 \\
\text { Pain: } 4\end{array}$ \\
\hline $\begin{array}{l}\text { Lobo et al[30] } \\
(2003)\end{array}$ & $\begin{array}{l}\mathrm{G}=1200 \mathrm{mg} / \mathrm{m} 2 \\
\text { Days } 1 \text { and } 8 \\
\mathrm{~V}=30 \mathrm{mg} / \mathrm{m} 2 \\
\text { Days } 1 \text { and } 8\end{array}$ & $\begin{array}{l}\text { Pretreated at least with } \\
\text { anthracyclines }\end{array}$ & 25 & 44 & $4.2 / \mathrm{ND}$ & $\begin{array}{l}\text { N: } 52 \\
\text { T: } 20 \\
\text { A: } 8\end{array}$ & $\begin{array}{l}\text { N/V: } 12 \\
\text { Stomatitis: } 4 \\
\text { Alopecia: } 16 \\
\text { Infection: } 12 \\
\end{array}$ \\
\hline
\end{tabular}




\begin{tabular}{|c|c|c|c|c|c|c|c|}
\hline & Every 3 weeks & & & & & & $\begin{array}{l}\text { Constipation: } 4 \\
\text { Fatigue: } 4 \\
\text { Cutaneous toxicity: } 8\end{array}$ \\
\hline $\begin{array}{l}\text { Dinota et al[31] } \\
(2005)\end{array}$ & $\begin{array}{l}\mathrm{G}=1000 \mathrm{mg} / \mathrm{m} 2 \\
\text { Days } 1 \text { and } 8 \\
\mathrm{~V}=25 \mathrm{mg} / \mathrm{m} 2 \\
\text { Days } 1 \text { and } 8 \\
\text { Every } 3 \text { weeks }\end{array}$ & $\begin{array}{l}\text { Advanced breast cancer } \\
\text { in elderly patients }\end{array}$ & 34 & 53 & $\begin{array}{l}\text { ND/ND } \\
\text { (MDR: } \\
7-10)\end{array}$ & $\begin{array}{l}\mathrm{N}: 20 \\
\mathrm{~T}: 11 \\
\mathrm{~A}: 17\end{array}$ & $\begin{array}{l}\text { N/V: } 26 \\
\text { Constipation: } 14\end{array}$ \\
\hline $\begin{array}{l}\text { Shmid et al[32] } \\
\text { (2005) }\end{array}$ & $\begin{array}{l}\mathrm{G}=350 \mathrm{mg} / \mathrm{m} 2 \\
\text { Days } 1 \text { and } 8 \\
\mathrm{~V}=25 \mathrm{mg} / \mathrm{m} 2 \\
\text { Days } 1 \text { and } 8 \\
\text { Every } 3 \text { weeks }\end{array}$ & $\begin{array}{l}\text { Pretreated with an- } \\
\text { thracyclines and/or } \\
\text { taxanes }\end{array}$ & 26 & 30.4 & $4.6 / 14.5$ & $\begin{array}{l}\mathrm{N}: 42 \\
\mathrm{~T}: 11.5 \\
\mathrm{~A}: 3.8\end{array}$ & $\begin{array}{l}\text { N/V: } 3.8 \\
\text { Diarrhea: } 3.8 \\
\text { Infection: } 11.5 \\
\text { Fatigue: } 3.8 \\
\text { Neuropathy : } 3.8 \\
\text { Liver Toxicity : } 3.8\end{array}$ \\
\hline $\begin{array}{l}\text { Gemnatas et } \\
\text { al[33] }(2006)\end{array}$ & $\begin{array}{l}\mathrm{G}=1000 \mathrm{mg} / \mathrm{m} 2 \\
\text { Days } 1 \text { and } 8 \\
\mathrm{~V}=25 \mathrm{mg} / \mathrm{m} 2 \\
\text { Days } 1 \text { and } 8 \\
\text { Every } 3 \text { weeks }\end{array}$ & $\begin{array}{l}\text { Heavily pretreated with } \\
\text { anthracyclines or taxanes }\end{array}$ & 86 & 36 & $\begin{array}{l}\text { ND/14 } \\
\text { (MDR: 7) }\end{array}$ & $\begin{array}{l}\mathrm{N}: 4.7 \\
\mathrm{~A}: 15.1 \\
\mathrm{~T}: 2.3\end{array}$ & None \\
\hline $\begin{array}{l}\text { Morabito et } \\
\text { al[34] }(2006)\end{array}$ & $\begin{array}{l}\mathrm{G}=800 \mathrm{mg} / \mathrm{m} 2 \\
\text { Days } 1 \text { and } 8 \\
\mathrm{~V}=25 \mathrm{mg} / \mathrm{m} 2 \\
\text { Days } 1 \text { and } 8 \\
\text { Every } 3 \text { weeks } \\
+ \\
\text { Weekly } \\
\text { Trastuzumab (4 } \\
\mathrm{mg} / \mathrm{kg} \text { on day } 0 \text {, } \\
\text { then } 2 \mathrm{mg} / \mathrm{kg})\end{array}$ & $\begin{array}{l}\text { Second-line treatment } \\
\text { HER-2/neu overex- } \\
\text { pressing } M B C\end{array}$ & 30 & 50 & $\begin{array}{l}\text { ND/15 } \\
\text { (PFS: 7) }\end{array}$ & $\begin{array}{l}\mathrm{N}: 20 \\
\mathrm{~T}: 3.3 \\
\mathrm{~A}: 3.3\end{array}$ & Fatigue: 13.3 \\
\hline $\begin{array}{l}\text { Ardavanis et } \\
\text { al[35] }^{[2007)}\end{array}$ & $\begin{array}{l}\mathrm{G}=1000 \mathrm{mg} / \mathrm{m} 2 \\
\text { Days } 1 \text { and } 14 \\
\mathrm{~V}=60 \mathrm{mg} / \mathrm{m} 2 \text { ORAL } \\
\text { Days } 1 \text { and } 14 \\
\text { Every } 4 \text { weeks }\end{array}$ & $\begin{array}{l}\text { Pretreated with an- } \\
\text { thracyclines } \\
74 \% \text { also treated with } \\
\text { taxanes }\end{array}$ & 31 & 35.4 & $5.3 / 14$ & $\begin{array}{l}\mathrm{N}: 3.22 \\
\mathrm{~N}: 3.22\end{array}$ & N/V: 3.22 \\
\hline $\begin{array}{l}\text { Zhou NN et } \\
\text { al[36] } \\
(2007)\end{array}$ & $\begin{array}{l}\mathrm{G}=1000 \mathrm{mg} / \mathrm{m} 2 \\
\text { Days } 1 \text { and } 8 \\
\mathrm{~V}=25 \mathrm{mg} / \mathrm{m} 2 \\
\text { Days } 1 \text { and } 8 \\
\text { Every } 3 \text { weeks }\end{array}$ & $\begin{array}{l}\text { Previously treated with } \\
\text { anthracyclines with or } \\
\text { without taxanes }\end{array}$ & 34 & 26.47 & $5.4 / 17.8$ & None & None \\
\hline $\begin{array}{l}\text { Kim et al[37] } \\
(2008)\end{array}$ & $\begin{array}{l}\mathrm{G}=1000 \mathrm{mg} / \mathrm{m} 2 \\
\text { Days } 1 \text { and } 8 \\
\mathrm{~V}=25 \mathrm{mg} / \mathrm{m} 2 \\
\text { Days } 1 \text { and } 8 \\
\text { Every } 3 \text { weeks }\end{array}$ & $\begin{array}{l}\text { Pretreated with an- } \\
\text { thracyclines and taxanes }\end{array}$ & 57 & 30 & $3.9 / 10.8$ & $\begin{array}{l}\mathrm{N}: 18.1 \text { (of cycles) } \\
\mathrm{T}: 0.7 \text { (of cycles) } \\
\mathrm{A}: 0.7 \text { (of cycles) }\end{array}$ & $\begin{array}{l}\text { Dyspnea: } 0.3 \text { (of cycles) } \\
\text { Liver toxicity: } 1.7 \text { (of } \\
\text { cycles) }\end{array}$ \\
\hline $\begin{array}{l}\text { Shehata et al[38] } \\
(2010)\end{array}$ & Not found & $\begin{array}{l}\text { First-line treatment in } \\
M B C \\
\text { All patients previously } \\
\text { treated with anthracy- } \\
\text { clines }\end{array}$ & 72 & 42 & $9.25 / \mathrm{ND}$ & $\begin{array}{l}\mathrm{N}: 10 \\
\mathrm{~T}: 1\end{array}$ & $\begin{array}{l}\text { Febrile N: } 11 \\
\text { Nausea: } 24 \\
\text { Stomatitis: } 11 \\
\text { Diarrhea: } 11\end{array}$ \\
\hline $\begin{array}{l}\text { Dong et al[39] } \\
(2012)\end{array}$ & $\begin{array}{l}\mathrm{G}=1000 \mathrm{mg} / \mathrm{m} 2 \\
\text { Days } 1 \text { and } 8 \\
\mathrm{~V}=25 \mathrm{mg} / \mathrm{m} 2 \\
\text { Days } 1 \text { and } 8 \\
\text { Every } 3 \text { weeks }\end{array}$ & $\begin{array}{l}\text { Elderly patients } \\
\text { Pretreated with an- } \\
\text { thracyclines and taxanes }\end{array}$ & 51 & 33 & $\begin{array}{l}\text { ND/17 } \\
\text { (PFS:6.2) }\end{array}$ & $\begin{array}{l}\mathrm{N}: 25.5 \\
\mathrm{~T}: 9.8 \\
\mathrm{~A}: 13.7\end{array}$ & $\begin{array}{l}\text { Fatigue : } 5.9 \\
\text { Constipation : } 3.9 \\
\text { Neuropathy : } 3.9 \\
\text { Liver toxicity : } 3.9\end{array}$ \\
\hline
\end{tabular}

Abbreviations: G- Gemcitabine, V-Vinorelbine, MBC-Metastatic breast cancer, TTP-Time to progression, OS-Overall survival, MDR-Median duration of response,

PFS-progression free survival, N-Neutropenia, T-Thrombocytopenia, A-Anemia, L-Leucopenia, N/V- Nausea or vomiting, ND-Not determined

\section{Conclusions}

In MBC patients who have been heavily pretreated with both anthracyclines and taxanes, the combination of $700 \mathrm{mg} / \mathrm{m}^{2}$ of gemcitabine by infusion, on days 1 and 8 and $15 \mathrm{mg} / \mathrm{m}^{2}$ of vinorelbine, by infusion, on days 2 and 9 every 21 days was ineffective, as it did not induce partial or complete responses. Grade 3 and 4 neutropenia occurred in 52\% of cycles, despite the lower doses of the combination compared with those in other phase II studies. Future studies should investigate the efficacy and tolerability of other chemotherapy agents or combinations in the treatment of anthracycline- and taxane-resistant MBC.

\section{Competing Interests}

The authors have declared that no competing interest exists.

\section{References}

1. Mayer EL, Burstein HJ. Chemotherapy for metastatic breast cancer. Hematol Oncol Clin North Am. 2007;21:257-72.

2. Kataja V, Castiglione M, for the ESMO Guidelines Working Group. Locally recurrent or metastatic breast cancer: ESMO clinical recommendations for diagnosis, treatment and follow-up. Ann Oncol. 2008; 19(Suppl 2 ii): 11-13.

3. Plunkett W, Huang P, Searcy CE, Gandhi V. Gemcitabine: preclinical pharmacology and mechanism of action. Semin Oncol. 1996; 23:3-15.

4. Silvestris N, D'Aprile A, Andreola G, et al. Rationale for the use of gemcitabine in breast cancer (review). Int I Oncol.2004; 24:389-98.

5. Albain KS, Nag SM, Calderillo-Ruiz G, et al. Gemcitabine plus paclitaxel versus paclitaxel monotherapy in patients with metastatic breast cancer and prior anthracycline treatment. J Clin Oncol.2008; 26(24):3950-7. 
6. Sánchez-Rovira P, Jaén A, González E, et al. Biweekly gemcitabine, doxorubicin, and paclitaxel as first-line treatment in metastatic breast cancer.Final results from a phase II trial. Oncology (Williston Park).2001; 15:44-7.

7. Conte PF, Gennari A, Donati S, et al. Gemcitabine plus epirubicin plus taxol (GET) in advanced breast cancer: a phase II study. Breast Cancer Res Treat. 2001; 68(2):171-9.

8. Zielinski C, Beslija S, Mrsic-Krmpotic Z, et al. Gemcitabine, epirubicin, and paclitaxel versus fluorouracil, epirubicin, and cyclophosphamide as first-line chemotherapy in metastatic breast cancer: a Central European Cooperative Oncology Group International, multicenter, prospective, randomized phase III trial. J ClinOncol.2005; 23(7):1401-8.

9. Ozkan M, Berk V, Kaplan MA, et al. Gemcitabine and cisplatin combination chemotherapy in triple negative metastatic breast cancer previously treated with a taxane/anthracycline chemotherapy; multicenter experience. Neoplasma.2012; 59(1):38-42

10. Nasr FL, Chahine GY, Kattan JG, et al. Gemcitabine plus carboplatin combination therapy as second-line treatment in patients with relapsed breast cancer. Clinical Breast Cancer. 2004 Jun;5(2):117-22.

11. Livingston RB, Ellis GK, Gralow JR, et al. Dose-intensive vinorelbine with concurrent granulocyte colony-stimulating factor support in paclitaxel-refractory metastatic breast cancer. J ClinOncol.1997; 15:1395-1400.

12. Zelek L, Barthier S, Riofrio M, et al. Weekly vinorelbine is an effective palliative regimen after failure with anthracyclines and taxanes in metastatic breast carcinoma. Cancer. 2001;92:2267-2272.

13. Domenech GH, Vogel CL. A review of vinorelbine in the treatment of breast cancer. Clin Breast Cancer.2001; 2:113-128.

14. Mano M. Vinorelbine in the management of breast cancer: New perspectives, revived role in the era of targeted therapy. Cancer Treat Rev. 2006; 32:106-118.

15. Vici P, Foggi P, Conte F, et al. Docetaxel and vinorelbine in anthracycline resistant breast cancer patients. Proc Am SocClinOncol. 2003; 22:71.

16. Polyzos A, Tsavaris N, Kosmas C, et al. Full dose paclitaxel plus vinorelbine as salvage chemotherapy in anthracycline-resistant advanced breast cancer: A phase II study. J Chemother.2003; 15:607-612.

17. Martín M, Lluch A, Casado A, et al. Paclitaxel plus vinorelbine: An active regimen in metastatic breast cancer patients with prior anthracycline exposure. Ann Oncol. 2000; 11:85-89.

18. Gómez-Bernal A, Cruz JJ, García-Palomo A, et al. Biweekly docetaxel and vinorelbine in anthracycline resistant metastatic breast cancer: A multicenter phase II study. Am J ClinOncol.2003; 26:127-131.

19. Blajman C, Balbiani L, Block J, et al. A prospective, randomized Phase III trial comparing combination chemotherapy with cyclophosphamide, doxorubicin, and 5-fluorouracil with vinorelbine plus doxorubicin in the treatment of advanced breast carcinoma. Cancer. 1999 Mar 1;85(5):1091-7.

20. Vassilomanolakis M, Koumakis G, Barbounis V, et al. Vinorelbine and cisplatin in metastatic breast cancer patients previously treated with anthracyclines. Ann Oncol. 2000; 11: 1155-1160.

21. Farhat FS, Temraz S, Kattan J, et al. A phase II study of lipoplatin (liposomal cisplatin)/vinorelbine combination in HER-2/neu-negative metastatic breast cancer. Clin Breast Cancer. 2011; 11(6):384-9.

22. Haider K, Kornek GV, Kwasny W, et al. Treatment of advanced breast cancer with gemcitabine and vinorelbine plus human granulocyte colony-stimulating factor. Breast Cancer Res Treat. 1999; 55(3):203-211.

23. Valenza R, Leonardi V, Gebbia V, et al. Gemcitabine and vinorelbine in pretreated advanced breast cancer: A pilot study. Ann Oncol. 2000; 11(4):495-496.

24. Nicolaides $C$, Dimopoulos MA, Samantas $E$, et al. Gemcitabine and vinorelbine as second-line treatment in patients with metastatic breast cancer progressing after first-line taxane-based chemotherapy: A phase II study conducted by the Hellenic Cooperative Oncology Group. Ann Oncol. 2000;11(7):873-875

25. Mariani G, Tagliabue $P$, Zucchinelli $P$, et al. Phase I/II study of gemcitabine in association with vinorelbine for metastatic breast cancer. Breast Cancer Res Treat. 2001; 70:163-169.

26. Sanal S, Gokmen E, Karabulut B, et al. A phase II study of gemcitabine (G) and vinorelbine $(\mathrm{V})$ in patients with advanced breast cancer. Proc Am SocClinOncol. 2000; 19:110a.

27. Stathopoulos GP, Rigotos SK, Pergantas N, et al. Phase II trial of biweekly administration of vinorelbine and gemcitabine in pretreated advanced breast cancer. J ClinOncol.2002; 20:37-41.

28. Donadio M, Ardine M, Berruti A, et al. Gemcitabine and vinorelbine as second-line treatment in patients with metastatic breast cancer: a phase II study. Cancer ChemotherPharmacol.2003; 52:147-152.

29. Morabito A, Filippelli G, Palmeri S, et al. The combination of gemcitabine and vinorelbine is an active regimen as second-line therapy in patients with metastatic breast cancer pretreated with taxanes and/or anthracyclines: a phase I-II study. Breast Cancer Research and Treatment.2003; 78: 29-36.

30. Lobo F, Virizuela JA, Dorta FJ, et al. Gemcitabine/vinorelbine in metastatic breast cancer patients previously treated with anthracyclines: Results of a phase I1 trial. Clin Breast Cancer. 2005;4:46-50.

31. Dinota A, Bilancia D, Romano R, et al. Biweekly administration of gemcitabine and vinorelbine as first line therapy in elderly advanced breast cancer. Breast Cancer Res Treat. 2005; 89(1): 1-3.

32. Schmid P, Heilmann V, Schulz CO, et al. Gemcitabine as prolonged infusion and vinorelbine in anthracycline and/or taxane pretreated metastatic breast cancer: a phase II study. J Cancer Res ClinOncol. 2005; 131: 568-574.
33. Gennatas C, Michalaki V, Mouratidou D, et al Gemcitabine in combination with vinorelbine for heavily pretreated advanced breast cancer. Anticancer Res. 2006; 26(1B): 549-552.

34. Morabito A, Longo R, Gattuso D, et al. Trastuzumab in combination with gemcitabine and vinorelbine as second-line therapy for HER-2/neu overexpressing metastatic breast cancer. Oncol Rep.2006; 16(2):393-8.

35. Ardavanis A, Kountourakis P, Maliou S, et al. Gemcitabine and oral vinorelbine as salvage treatment in patients with advanced anthracycline and taxane-pretreated breast cancer. Anticancer Research.2007;27: 2989-2992.

36. Zhou NN, Teng XY, Jiang WQ. Efficacy and toxicity of gemcitabine combined vinorelbine on metastatic breast cancer: a report of 34 cases. Ai Zheng. 2007; 26(12):1373-6.

37. Kim HJ, Kim JS, Seo MD, et al. Gemcitabine and vinorelbine combination chemotherapy inanthracycline- and taxane-pretreated advanced breast cancer. Cancer Res Treat. 2008;40(2):81-86.

38. Shehata S, Saad E, Goda Y, et al. A phase II study of gemcitabine combined with vinorelbine as first-line chemotherapy for metastatic breast cancer. Hematol Oncol Stem Cell Ther. 2010; 3(1):1-6.

39. Dong N, Wang M, Li H, et al. Gemcitabine in combination with vinorelbine in elderly patients with anthracycline- and taxane-pretreated metastatic breast cancer. Cancer ChemotherPharmacol. 2012; 69 (5):1315-22.

40. Halim A, Wahba $\mathrm{H}$. Second-line neoadjuvantvinorelbine and gemcitabine combination in locally advanced breast cancer showing no early response to TAC. Med Oncol. 2011.

41. Martín M, Ruiz A, Muñoz M, et al. Gemcitabine plus vinorelbine versus vinorelbinemonotherapy in patients with metastatic breast cancer previously treated with anthracyclines and taxanes: final results of the phase III Spanish Breast Cancer Research Group (GEICAM) trial. Lancet Oncol. 2007 Mar;8(3):219-25

42. Stemmler HJ, diGioia D, Freier W, et al. Randomised phase II trial of gemcitabine plus vinorelbinevs gemcitabine plus cisplatinvs gemcitabine plus capecitabine in patients with pretreated metastatic breast cancer. Br J Cancer. 2011 Mar 29;104(7):1071-8

43. Pallis AG, Boukovinas I, Ardavanis A, et al. A multicenter randomized phase III trial of vinorelbine/gemcitabine doublet versus capecitabine monotherapy in anthracycline- and taxane-pretreated women with metastatic breast cancer. Annals of Oncology. 2011 Sept 21.

44. Amadori D, Carrasco E, Roesel $S$, et al A randomized phase II non-comparative study of pemetrexed-carboplatin and gemcitabine-vinorelbine in anthracycline- and taxane-pretreated advanced breast cancer patients. Int J Oncol. 2013 May; 42(5):1778-85. 